\title{
SOSIALISASI GLOBAL CITIZENSHIP KEPADA SISWA SDN 08 BUNGKANG KECAMATAN SEKAYAM KABUPATEN SANGGAU
}

\author{
Adityo Darmawan Sudagung, Laras Putri Olifiani
}

\author{
${ }^{1}$ Program Studi Hubungan Internasional, Fakultas Ilmu Sosial dan Ilmu Politik, \\ Universitas Tanjungpura
}

\begin{abstract}
Abstrak
Kegiatan ini dilatarbelakangi oleh rendahnya kualitas sumber daya manusia di kawasan perbatasan Indonesia-Malaysia di Kalimantan Barat. Hanya ada tiga kabupaten/kota yang angka Indeks Pembangunan Manusua (IPM) berada di atas rata-rata provinsi. Bahkan jika dibandingkan dengan IPM nasional tahun 2018, hanya ada dua kabupaten/kota di Kalimantan Barat yang berada di atas angka tersebut. Kalimantan Barat menduduki peringkat IPM 30 dari 34 provinsi di tahun 2018. Kondisi sekolah di kawasan perbatasan juga memiliki fasilitas sekolah yang minim ditambah dengan akses informasi dan bahan bacaan yang juga tidak mendukung. Sehingga rendahnya -kesadaran sebagai warga dunia seperti yang diinginkan dalam tujuan pembangunan berkelanjutan tidak dapat dicegah. Kegiatan bertujuan menambahkan kesadaran siswa di SDN 08 Bungkang terhadap pentingnya menjadi warga dunia. Kegiatan ini dilakukan selama satu hari dengan peserta sekitar 80 siswa. Metode yang digunakan adalah ceramah tentang literasi sebagai jendela dunia, diskusi, dan permaian interaktif. Permainan interaktif kami namai "Keliling Dunia" dengan mengadopsi konsep permainan monopoli. Melalui kegiatan ini kami menyimpulkan bahwa para siswa begitu antusias untuk menambah wawasan tentang masyarakat dunia. Pihak sekolah juga mengapresiasi penyampaian materi yang lebih segar dan penting untuk masa depan siswa.
\end{abstract}

Kata kunci: masyarakat dunia, cosmopolitanism, literasi

\begin{abstract}
This program was initiated based on the background of low-level quality in human resources at the Indonesia-Malaysia border area, especially at West Borneo. There were only three regions which Human Development Index (HDI) higher than the provincial average rate. Even if compared to national HDI in 2018, only two region/city in West Borneo had a better rate. West Borneo was the $30^{\text {th }}$ rank over $34^{\text {th }}$ province in Indonesia based on their HDI. Schools condition at border area had lack of facilities, limited access to information and references. Therefore lack of awareness as a global citizen like the sustainable development goals target was something unpreventable. The aim of this program was increasing the awareness of student at SDN 08 Bungkang for the importance of being global citizenship. It was conducted in one day with approximately 80 students. We used lecturing about literation as the window for the world, discussion, and interactive game. The interactive game we called "Keliling Dunia" by adopting the monopoly game's concept. Through this program, we discovered that the students were so excited to enlarge their knowledge about the global citizen. The school also appreciated the fresh and important knowledge we presented for the future of their students.
\end{abstract}

Keywords: global citizenship, cosmopolitanism, literacy

Correspondence author: Adityo Darmawan Sudagung, adityo.ds@fisip.untan.ac.id, Pontianak, Indonesia

This work is licensed under a $C C-B Y-N C$ 


\section{PENDAHULUAN}

Dunia internasional terus mengalami perkembangan yang menyebabkan penyesuaian dari para penstudi Hubungan Internasional. Memasuki akhir Perang Dunia I, studi Hubungan Internasional mulai secara resmi dipelajari dengan nama International Politics menempatkan kajian atas negara-negara untuk mencapai perdamaian. Begitu juga dengan fase setelah Perang Dunia II memunculkan teori realisme yang gandrung akan keunggulan negara sebagai satu-satunya aktor yang menyebabkan sistem internasional menjadi anarki.

Pada kelanjutan fase perkembangan dunia tersebut, para penstudi Hubungan Internasional dihadapkan dengan dilema-dilema yang menggoyahkan keberadaan negara sebagai satu-satunya aktor yang mewarnai hubungan internasional. Ditandai dengan kemunculan aktor-aktor non-negara, seperti organisasi internasional, lembaga swadaya masyarakat internasional, perusahaan multinasional, bahkan individu, yang mampu memberikan tekanan-tekanan politis kepada negara. Bahkan juga disertai dengan perluasan sektor dalam studi Hubungan Internasional. Contohnya adalah studi keamanan yang tidak lagi mengaji masalah-masalah perang dan persenjataan, tapi sudah diperluas hingga menganalisa masalah keamanan terkait perekonomian, identitas kolektif, lingkungan, bahkan manusia.

Sejalan dengan perkembangan fenomena tersebut, terdapat salah satu teori yang menarik menjelaskan pentingnya individu di dunia untuk mengedepankan isu kemanusiaan, yaitu teori cosmopolitanism. Teori ini menjadi salah satu alternatif dalam melihat fenomena hubungan internasional yang semakin dinamis.

Teori cosmopolitanism dalam studi Hubungan Internasional dapat ditelusuri dari pendapat Smith dan Owens (2005, dalam Sudagung, 2015 dan Sudagung, 2018) sebagai cara pandang yang memfokuskan teori normatif politik dunia harus berkonsentrasi pada kemanusiaan secara keseluruhan atau individu. Pendapat lainnya mengenai teori ini juga dijelaskan oleh Hooft dan Vandekerckhove (2010, dalam Sudagung, 2015 dan 2018) sebagai suatu upaya mengakomodir program bantuan yang lebih baik dan luas, lebih terbuka, peduli terhadap pelanggaran hak asasi manusia di mana saja dan memberikan respon terhadap isu tersebut.

Cosmopolitanism mendapatkan tempat sejalan dengan dasar pemikiran English School yang menjelaskan fase realitas hubungan internasional. Tiga landasan utama tersebut adalah sistem internasional (international system), masyarakat internasional (international society), dan masyarakat dunia (world society). Filosofi utama pendirian mazhad English School menurut Buzan (2004: 10) terletak pada ide bahwa ketiga konsep tersebut terwujud secara simultan (pada waktu yang bersamaan), baik sebagai objek diskusi dan aspek realitas internasional.

Fase realitas yang menarik dibahas seiring perkembangan pesat fenomena globalisasi adalah masyarakat dunia. Sebuah pertanyaan besar yang dapat diangkat adalah: Sudahkah kita di abad ke-21 ini benar-benar memasuki fase tersebut? Pertanyaan ini sekaligus dapat menjawab pertanyaan sebelumnya mengenai dasar filosofis dari Teori English School: Apakah benar ketiga fase tersebut berjalan secara simultan? Atau ketiganya merupakan fase perkembangan yang berkelanjutan?

Pertanyaan-pertanyaan ini dapat dijawab beriringan dengan bantuan teori cosmopolitanism yang menempatkan individu sebagai objek sekaligus aktor hubungan internasional. Melalui pendekatan isu kemanusiaan yang bersifat universal, pendekatan ini membantu peneliti Hubungan Internasional menjawab tantangan dari 
keberlangsungan fase masyarakat dunia. Masyarakat dunia menurut Buzan (2004) merupakan bagian dari pemikiran Kant yang mengusung filosofi revolusionalisme dengan menempatkan individu, organisasi non-negara, dan populasi global sebagai satu kesatuan yang menjadi fokus dari identitas dan pengaturan masyarakat global.

Salah satu fenomena yang paling terasa adalah dengan kemunculan konsep global citizenship dan target pembangunan keberlanjutan (sustainable development goals). Kemunculan fenomena di atas tidak lepas dari pertumbuhan keterhubungan antara manusia, negara, dan ekonomi yang membuat kita merasa perlu melihat diri sebagai bagian dari sesuatu entitas yang global (Israel, 2012).

Konsep global citizenship berasal dari kemunculan konsep global citizen yang merupakan seseorang yang hirau dan paham mengenai dunia luas dan peran mereka bagi dunia. Orang-orang ini mengambil peran aktif dalam komunitas dan bekerja dengan orang lainnya untuk mewujudkan dunia yang lebih merata, adil, dan berkelanjutan (https://www.oxfam.org.uk/education/who-we-are/what-is-global-citizenship). Menurut Oxfam (https://www.oxfam.org.uk/education/who-we-are/what-is-global-citizenship), global citizenship merupakan suatu program yang mendorong generasi muda untuk mengembangkan pengetahuan, kemampuan, dan nilai yang dibutuhkan untuk melakukan hubungan lintas dunia.

Target pembangunan berkelanjutan sendiri merupakan tujuan bersama pembangunan dunia 2030 yang memuat 17 tujuan dan 169 indikator capaian global. Salah satu indikator yang menjadi fokus dalam tulisan ini adalah pendidikan berkualitas. Sebagai pendukung utama peningkatan kualitas sumber daya manusia, faktor pendidikan berkualitas menjadi hal yang wajib dicapai. Sejalan dengan itu, Presiden Indonesia, Joko Widodo, dalam visi Nawa Cita mencantumkan dua aspek yang sangat krusial dalam pembangunan sumber daya manusia. Pertama, visi ketiga membangun Indonesia dari pinggiran dengan memperkuat daerah-daerah dan desa dalam kerangka negara kesatuan. Kedua, visi kelima meningkatkan kualitas hidup manusia Indonesia melalui peningkatan kualitas pendidikan dan pelatihan dengan program "Indonesia Pintar"; serta peningkatan kesejahteraan masyarakat dengan program "Indonesia Kerja" dan "Indonesia Sejahtera" dengan mendorong land reform dan program kepemilikan tanah seluas 9 hektar, program rumah kampung deret atau rumah susun murah yang disubsidi serta jaminan sosial untuk rakyat di tahun 2019 .

Meskipun demikian visi tersebut selama lima tahun masih sulit untuk diwujudkan, khususnya di kawasan perbatasan Indonesia. Di Kalimantan Barat sebagai salah satu provinsi yang berbatasan langsung dengan Malaysia pembangunan infrastruktur perbatasan, berupa jalan dan pos linta batas dirasa belum cukup membenahi kebutuhan peningkatan sumber daya manusia Indonesia. Menurut data dari BPS (2018) hanya tiga kabupaten/kota yang angka Indeks Pembangunan Manusia (IPM) berada di atas rata-rata provinsi. Bahkan jika dibandingkan dengan IPM nasional tahun $2018(70,81)$, hanya ada dua kabupaten/kota di Kalimantan Barat yang berada di atas angka tersebut (BPS, 2018). Kalimantan Barat menduduki peringkat IPM 30 dari 34 provinsi. (BPS, 2018).

Salah satu potret dari masih rendahnya pendidikan di Kalimantan Barat terlihat dari pemberitaan di laman Antarafoto.com pada tanggal 27 Februari 2019. Laman tersebut memberitakan sejumlah 42 siswa kelas 3 dan 5 SDN 08 Bungkang Kecamatan Sekayam Kabupaten Sanggau duduk di lantai saat belajar di bekas rumah guru (https://www.antarafoto.com/peristiwa/v1551273011/belajar-di-bekas-rumah-dinas-

guru). Fenonema di salah satu kawasan perbatasan menunjukkan bahwa visi besar Presiden Joko Widodo belum benar-benar terlaksana dengan optimal. Hal ini didukung 
dengan pernyataan dari Bupati Sintang pada tahun 2017 yang menyebutkan bahwa tingkat pendidikan di Kabupaten Sanggau masih rendah (https://www.suarapemredkalbar.com/berita/sanggau/2017/12/13/bupati-sebut-tingkatpendidikan-masih-rendah).

Fakta menunjukkan kondisi sekolah di kawasan perbatasan tersebut memiliki fasilitas sekolah yang minim ditambah dengan akses informasi dan bahan bacaan yang juga tidak mendukung. Hal ini jelas membuat para siswa dan juga guru menjadi kesulitan dalam meningkatkan wawasan yang berujung pada upaya peningkatan kualitas pendidikan. Belum lagi jika berbicara menumbuhkan kesadaran sebagai warga dunia seperti yang diinginkan dalam tujuan pembangunan berkelanjutan yang didukung dengan pendekatan cosmopolitanism dalam studi Hubungan Internasional.

Dengan semangat mewujudkan tujuan pembangunan berkelanjutan 2030 dan global citizenship menurut kami perlu diadakan pengenalan sejak dini perkembangan negara dan keunggulan masing-masing. Pengenalan atas kekuatan masing-masing negara melalui pendekatan keamanan, sosial, ekonomi, dan kebudayaan. Untuk itu diperlukan penyampaian informasi mengenai konsep global citizenship guna membukakan wawasan tentang dunia yang bisa dipelajari dari pelosok negeri bagi siswa sekolah dasar di kawasan perbatasan. Sehingga diharapkan menggugah semangat siswa di perbatasan merasa sebagai bagian dari warga dunia.

Tujuan dilakukannya kegiatan PKM di SDN 08 Bungkang Kecamatan Sekayam Kabupaten Sanggau, antara lain,1) menyampaikan materi mengenai menjadi warga negara dunia melalui pengenalan peta dunia dan profil negara kepada siswa dan guru, 2) menjalin kerja sama dan hubungan baik dengan sekolah khususnya terkait pengembangan sumber daya manusia sesuai dengan target pembangunan berkelanjutan global.

Sementara manfaat yang diharapkan tercapai melalui kegiatan PKM di SDN 08 Bungkang Kecamatan Sekayam Kabupaten Sanggau, antara lain, 1) para siswa dan guru memiliki pemahaman sebagai bagian dari warga dunia melalui pehamahan atas peta dunia dan profil negara-negara yang ada, 2) memberikan masukan kepada pihak sekolah atau pemerintah daerah terkait pengembangan pembelajaran yang berorientasi pada isu global.

\section{METODE PELAKSANAAN}

Pelaksanaan Pengabdian Kepada Masyarakat oleh Tim Pengajar dari Fakultas Ilmu Sosial dan Ilmu Politik Universitas Tanjungpura ini mengambil lokasi di SDN 08 Bungkang Kecamatan Sekayam Kabupaten Sanggau. Sasaran kegiatan Pengabdian Kepada Masyarakat adalah kepala sekolah, jajaran guru, dan siswa SDN 08 Bungkang Kecamatan Sekayam Kabupaten Sanggau.

Permasalahan minimnya akses informasi dan fasilitas yang dihadapi oleh sekolah butuh penyelesaian yang signifikan jika dikaitkan dengan isu global citizenship dan target pembangunan berkelanjutan 2030. Untuk itu tim pengajar berinsiatif mempelopori pengenalan terhadap dunia kepada siswa dan guru di kawasan perbatasan IndonesiaMalaysia. Dalam melakukan kegiatan ini melibatkan beberapa mitra pelaksana yang terdiri dari:

1. Tim pengajar (dosen) adalah Adityo Darmawan Sudagung, S.H.Int., M.I.Pol. dan Laras Putri Olifiani, S.IP., M.HI. dan dibantu tim mahasiswa S1 Program Studi Hubungan Internasional FISIP UNTAN, yaitu Veronica Putri, Ivan Sasiva Rizky, dan Joy Evan; 
2. Kompas TV selaku mitra komunikasi dan informasi yang akan melakukan peliputan kegiatan dengan tujuan menyampaikan kepada warga dunia kegiatan yang dilakukan dan kondisi sekolah di Kecamatan Sekayam.

3. Kepala Sekolah, jajaran guru, dan siswa SD 42 Sekayam Kecamatan Entikong Kabupaten Sanggau selaku peserta sosialisasi dan diskusi.

Peserta sosialisasi berjumlah sekitar 80 orang, yaitu siswa kelas 4, 5, dan 6 yang dibagi ke dalam dua ruang kelas. Kelas pertama diisi dengan materi bertema literasi sebagai jendela dunia. Sementara kelas kedua diadakan permainan Keliling Dunia. Selain itu, kami juga membagikan sumbangan bahan bacaan sekolah dan majalah, alat tulis bagi peserta didik, dan permainan puzzle bendera negara dunia ke pihak SDN 08 Bungkang. Pelaksanaan kegiatan PKM Tim Dosen FISIP UNTAN ini dimulai sejak Mei 2019 hingga Agustus 2019. Pelaksanaan sosialisasi telah dilaksanakan pada tanggal 27 Juli 2019. Jadwal kegiatan PKM secara rinci adalah sebagai berikut:

Tabel 1. Jadwal Kegiatan

\begin{tabular}{llllll}
\hline \multirow{2}{*}{ No. } & \multicolumn{1}{c}{ Kegiatan PKM } & \multicolumn{4}{c}{ Bulan ke- } \\
\cline { 3 - 6 } 1 & Persiapan & & & \\
\cline { 3 - 6 } & & & & & \\
2 & $\begin{array}{l}\text { Pembuatan } \\
\text { Pelatihan dan Permainan }\end{array}$ & & & \\
3 & Pelaksanaan Kegiatan & & & \\
4 & Evaluasi Kegiatan & & & \\
\hline
\end{tabular}

\section{HASIL DAN PEMBAHASAN}

Melihat fenomena masih rendahnya pendidikan di daerah perbatasan menjadi permasalahan bersama untuk dapat terlepas dari belenggu kemunduran intelektual sehingga mampu dapat menyongsong semangat Indonesia Unggul atau "SDM Unggul Indonesia Maju" sesuai dengan tema Hari Republik Indonesia yang terinspirasi dari visi Presiden Joko Widodo untuk pemerintahan periode kedua akan lebih berfokus pada pembangunan sumber daya manusia. Jargon tersebut menjadi pendorong bagi bangsa Indonesia untuk dapat maju dan bahkan mampu berkompetisi di tingkat global.

Untuk dapat mendukung tercapainya visi tersebut diperlukan koordinasi seluruh pihak, baik yang sifatnya state hingga non- state. Cosmopolitanism merupakan hal yang sejalan dalam merespon dinamika isu hubungan internasional pada era globalisasi ini, terutama pada fokus penelitian adalah permasalahan rendahnya tingkat pendidikan masyarakat Indonesia. Hal ini memiliki pengaruh pada kualitas Sumber Daya Manusia untuk dapat menjadi masyarakat dunia. Sesuai dengan yang dipaparkan oleh Anthony Giddens bahwa globalisasi menjadikan semua elemen masyarakat dalam satu dunia. Hal itu terjadi dikarenakan globalisasi meningkatkan interdependensi antar negara, antar daerah bahkan antar manusia. Melalui perkembangan fenomena tersebut, maka terdapat salah satu teori yang menarik menjelaskan pentingnya individu di dunia untuk mengedepankan isu kemanusiaan, yaitu teori cosmopolitanism. Teori tersebut sudah kami jelaskan di awal terkait cara pandang yang memfokuskan teori normatif politik dunia 
harus berkonsentrasi pada kemanusiaan secara keseluruhan atau individu. Upaya yang dapat dilakukan menurut pemikir cosmopolitanism adalah mengakomodir program bantuan yang lebih baik dan luas, lebih terbuka, peduli terhadap pelanggaran hak asasi manusia di mana saja dan memberikan respon terhadap isu tersebut.

Hal tersebut sekaligus menjadi tantangan bagi pendidikan di Indonesia, untuk merespon berbagai tantangan tersebut diperlukan sinergi dari berbagai pihak terutama peran non-state actor untuk mewujudkan Global Citizenship. Memberikan kesadaran pada berbagai elemen masyarakat akan pentingnya rasa solidaritas atas masyarakat dunia. Hal itu dapat dirumuskan dalam pemahaman pendidikan global yang sudah seharusnya diterima oleh seluruh masyarakat dunia. Hal itu menjadi begitu penting karena pendidikan yang berwawasan global dapat menjadi pengetahuan untuk mengembangan kesadaran setiap individu dalam memahami masyarakat yang telah menjadi satu (global village) serta isu-isu global.

Untuk mendorong rasa solidaritas Global Citizenship sebagai bahan rujukan dari penelitian ini, hal tersebut diawali dengan persiapan melakukan diskusi penentuan tema kegiatan sosialisasi. Dipilihlah isu yang relevan dengan bidang studi yang dikuasai, yaitu Global Citizenship dengan memberikan pemahaman pendidikan global kepada peserta didik. Pemahaman pendidikan global tersebut pada penelitian ini merujuk pada Carlos Diaz, Massialas, dan Xanthopoulus (1999) yang memaknai pendidikan global sebagai pendidikan yang bertujuan untuk membantu siswa memahami konsep-konsep global dan isu-isu dan mengarahkan pula kepada tindakan sebagai warga negara. Pemahaman pendidikan global yang ditawarkan adalah dengan memberikan materi kepada peserta didik terkait informasi negara-negara dunia dengan karakteristik keunggulan setiap negara.

Diskusi dilanjutkan dengan penentuan waktu survei untuk lebih memahami karakter daerah tujuan. Survei juga direncanakan untuk mengetahui sasaran sosialisasi yang tepat. Diskusi lainnya yang dilakukan adalah membahas teknis sosialisasi dan bahan-bahan yang akan dijelaskan kepada masyarakat. Hasil diskusi adalah sosialisasi akan dilakukan dengan memperkenalkan negara-negara dunia dengan metode pembelajaran bermain menggunakan monopoli. Selain itu, disepakati bahwa materi yang diberikan juga menjelaskan terkait pentingnya khazanah literasi bagi peserta

Survei dilakukan pada tanggal 8 Juli 2019 untuk memastikan waktu sosialisasi. Survei dilakukan dengan mendatangi Kepala SDN 08 Bungkang Kecamatan Sekayam. Setelah survei juga dijalin komunikasi melalui telepon seluler untuk mematangkan persiapan sosialisasi. Sosialisasi direncanakan dilakukan dengan sasaran pelajar SDN 08 Bungkang Kecamatan Sekayam. Hasil survei disepakati bahwa kegiatan sosialisasi akan dilaksanakan pada akhir bulan Juli, yaitu pada tanggal 29 Juli 2019. Kami juga menemukan hal yang menarik di SDN 08 Bungkang, yaitu di dinding sekolah terdapat gambar bendera-bendera negara ASEAN dan Timor Leste. Kami sangat senang karena di perbatasan negara, kesadaran akan pengetahuan dunia internasional sudah dimiliki. Namun, ternyata ketika diwawancarai ternyata motif lukisan bendera tersebut hanya karena ingin mengikuti yang sudah ada di SDN lain di kota kabupaten. Kegiatan survei ditindaklanjuti dengan melakukan rapat hasil survei. Pada rapat tersebut dibagikan tugastugas pengumpulan materi dan pembuatan tayangan sosialisasi.

Hambatan yang ditemukan adalah penentuan tanggal pelaksanaan. Dikarenakan pada bulan Juli tersebut peserta didik tidak dalam proses belajar-mengajar (libur). Peneliti mengupayakan komunikasi yang sangat intens dengan pihak yang berwenang di SDN 08 Bungkang Kecamatan Sekayam. Pada sosialisasi yang diadakan di Kelas IV, V, dan VI 
SDN 08 Bungkang Kecamatan Sekayam, dihadiri oleh 80 peserta dan juga dihadiri oleh Kepala Sekolah.

Peneliti sempat mengalami kendala karena pada hasil survei disepakati bahwa peserta hanya terdiri dari dua kelas saja, atau sekitar 60 orang. Namun, ternyata terdapat miskomunikasi dengan pihak sekolah sehingga sudah menyiapkan siswa kelas 4-6 yang berjumlah 80 orang. Sehingga kondisi ruangan yang merupakan dua kelas dijadikan satu ruangan menjadi sangat padat dan kurang kondusif. Tim kemudian berinsiatif pada hari $\mathrm{H}$ untuk membagi target audiens menjadi dua kelas. Satu ruang kelas untuk materi literasi dan satu ruang kelas untuk materi pengenalan dunia. Dengan tidak mengurangi bobot kualitas penyampaian, kami meyakini membagi jumlah audiens akan lebih efektif terserap.

Kegiatan pada sesi pertama yang kami lakukan adalah memberikan pemahaman mengenai pentingnya literasi kepada para siswa. Pada materi pertama, disampaikan pentingnya membaca dan mencari pengetahuan. Pemateri kami melakukan model permainan gambar dan simulasi gerakan-gerakan sesuai instruksi, lihat gambar 1. Hal ini didasari pada objek sosialisasi yang merupakan siswa SD. Pentingnya materi ini menurut kami merupakan jembatan informasi bagi siswa di kawasan perbatasan dengan perkembangan informasi yang juga beredar di daerah perkotaan. Di samping itu, kami juga mengadakan diskusi ringan terkait cita-cita dan harapan para siswa perbatasan.

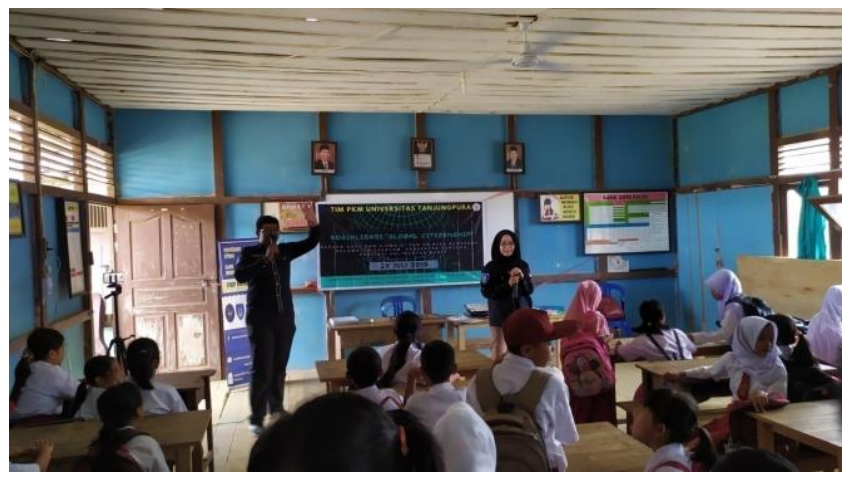

Gambar 1 Tim PKM menyampaikan informasi-informasi terkait literasi

Para siswa juga ditantang untuk mengeksplorasi pengalaman belajar serta keseharian mereka sebagai warga perbatasan. Seperti contoh, tim meminta salah satu siswa menceritakan pengetahuan yang didapatkan selama kegiatan belajar mengajar dalam seminggu terakhir. Bahkan beberapa orang siswa dengan insiatif diri ingin menceritakan kisah suka dan duka dalam belajar di tingkat sekolah dasar. Salah satu siswa juga berani untuk tampil ke depan untuk bernyanyi menghibur teman-teman di kelas.

Penyampaian materi terkait literasi menurut kami berjalan dengan baik. Terlihat dari antusiasme para siswa dalam mengikuti kegiatan tersebut. Meskipun kami merasakan pemaparan kurang maksimal dikarenakan jumlah peserta yang melebihi kapasitas ruangan. Setelah berjalan empat puluh lima menit, tim memutuskan untuk membagi peserta menjadi dua kelompok besar. Kelompok pertama melanjutkan kegiatan bertemakan literasi, sementara kelompok kedua dengan tema wawasan dunia melalui permainan "Keliling Dunia". Gambar papan permainan dapat dilihat pada gambar 2. 


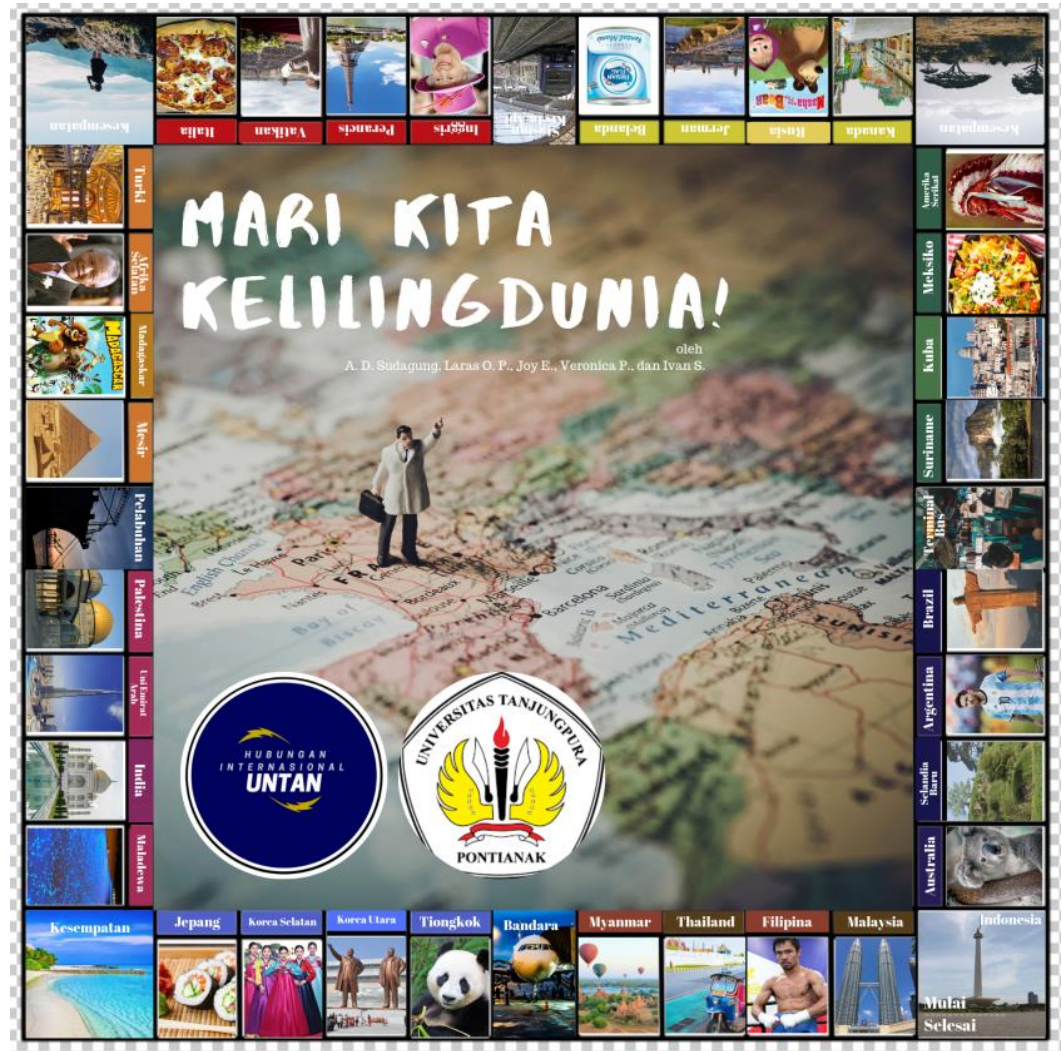

Gambar 2 Papan Permainan Keliling Dunia

Papan permainan ini dibuat sebagai sebuah alat peraga untuk mengenalkan kepada siswa informasi seputar negara-negara di dunia. Selain nama negara, kami juga menambahkan kekhasan dari tiap negara dalam bentuk foto. Konsep permainan ini menyadur dari gagasan bermain monopoly dengan papan permainan, dadu, dan kartu penjelasan tiap kotak. Penyesuaian kami lakukan dalam isian kotak dan teknis permainan.

Permainan yang kami beri nama Keliling Dunia didukung dengan beberapa alat bantu yang dibutuhkan, yaitu: papan permainan yang dilengkapi petak-petak bergambar dengan jumlah 33 petak negara, 3 petak kesempatan, dan 4 petak; satu buah dadu untuk mengetahui hitungan jumlah petak yang akan ditempati; buku saku Keliling Dunia yang berisi profil-profil negara sesuai komplek yang terdapat pada papan permainan; dan kertas warna-warni / sticky note yang digunakan sebagai bidak permainan tiap peserta.

Sebelum melakukan permainan sebagai bagian dari sosialisasi, kami perlu menjelaskan aturan permainan kepada para peserta. Penjelasan aturan permainan dimulai dengan tahap persiapan permainan, yaitu:

1. Sebelum memulai permainan, bentangkan papan permainan pada dinding, papan tulis, ataupun lantai sesuai dengan persetujuan semua peserta.

2. Permainan dapat dimainkan dengan jumlah peserta minimal 2 orang. Namun jika ingin bermain dalam jumlah peserta yang banyak, setidaknya bentuklah beberapa kelompok untuk mempermudah dalam menentukan jumlah bidak yang ikut dalam permainan.

3. Setelah menentukan kelompok, buatlah kolom penilaian sesuai dengan jumlah peserta / kelompok yang ikut dalam permainan. 
4. Tunjuklah satu orang yang berpredikat netral (tidak memihak kepada siapapun) sebagai pengadil dan pemberi pertanyaan, sekaligus untuk mengatur jalannya permainan.

5. Setelah menentukan jumlah peserta / kelompok yang akan ikut dalam permainan, peserta menentukan warna kertas / bidak yang akan dipakai dalam permainan agar tidak tertukar dengan bidak peserta lain.

6. Setelah segala persiapannya selesai, permainan siap untuk dimulai.

Selanjutnya tim melakukan beberapa tahapan permainan diawali dengan setiap kelompok yang ikut dalam permainan diharuskan untuk melempar dadu terlebih dahulu secara bergiliran. Peserta/kelompok yang memiliki angka dadu tertinggi mendapat giliran main terlebih dahulu, diikuti dengan peserta lainnya sampai angka dadu terkecil. Setiap kelompok bergiliran melemparkan dadu untuk menjalankan bidanknya. Ketika sampai pada suatu petak, akan teradapat beberapa kegiatan yang dalam dilakukan bergantung pada jenis petaknya.

Jenis petak dalam papan permainan ada beberapa jenis dan memiliki fungsi masingmasing. Misalnya petak negara, ketika bidak peserta tepat berhenti pada petak negara, maka orang yang berperan sebagai "Pengadil" akan membacakan sekilas mengenai profil-profil sesuai dengan negara yang ditempati oleh bidak peserta. Setelah selesai membacakan profil negara tersebut kepada peserta, "Pengadil" berhak memberikan pertanyaan berkaitan dengan profil negara yang telah dibacakan tadi. Peserta/kelompok yang bidaknya menempati petak negara tersebut harus menjawab pertanyakan yang telah diajukan oleh "Pengadil". Jika jawaban dari peserta/kelompok tersebut benar, maka akan diberikan score/nilai 10 dalam kolom penilaian. Namun jika jawaban dari peserta salah, pertanyaan akan dilempar kepada kelompok lainnya dengan sistem rebutan (siapa cepat, dia yang dapat) dengan cara mengangkat tangan secepat mungkin. Jika benar, maka kelompok lain yang menjawab pertanyaan tersebut akan mendapat score/nilai 10 .

Sementara petak kesempatan memiliki fungsi berbeda. Jika salah satu peserta/kelompok yang bidaknya tepat berhenti pada petak kesempatan, maka "Pengadil" akan membacakan pertanyaan pengetahuan umum. Pertanyaan pada petak kesempatan dapat dimodifikasi sesuai dengan materi pelajaran yang ada. Jika jawaban benar, maka peserta / kelompok yang menjawab benar mendapatkan score / nilai 20. Jika jawaban yang dikeluarkan peserta salah, maka pertanyaan akan dilempar kepada peserta lainnya dengan cara yang sama.

Adapun petak transportasi umum memiliki ketentuan antara lain ketika ada peserta/kelompok yang berhenti pada petak yang bergambarkan transportasi umum, maka peserta/ kelompok yang berhenti di petak tersebut berhak menunjuk kelompok lain untuk melakukan dan mempertontonkan bakat yang dimilikinya. Bakat tersebut dapat berupa: bernyanyi, menari, ataupun bakat lainnya. Ketika menampilkan bakatnya, peserta diberikan waktu maksimal 3 menit untuk menampilkan bakatnya. Setelah selesai menampilkan bakatnya, peserta/perwakilan kelompok dapat kembali duduk dan melanjutkan permainan sesuai urutan main selanjutnya. 


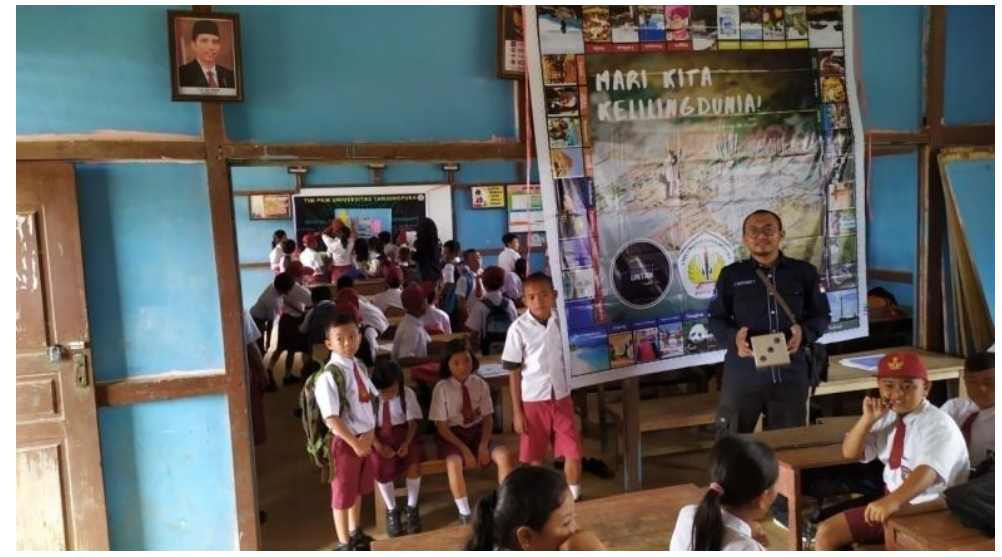

Gambar 3. Tim PKM mengajak peserta bermain Keliling Dunia

Pada praktiknya, permainan ini tidak bisa kami selesaikan hingga kelompok selesai menuju garis selesai. Karena waktu yang disediakan oleh pihak sekolah hanya sekitar 2 jam. Sementara proses permainan dengan kelompok yang berjumlah 6 tim membutuhkan waktu yang lebih lama. Selain karena jumlah tim yang cukup banyak, ternyata proses bergiliran dalam menjawab dan merebut jawaban pertanyaan tim lain membutuhkan waktu yang lebih.

Temuan kami menunjukkan bahwa tidak banyak siswa mengenali keseluruhan nama negara yang kami tampilkan pada papan permainan. Untuk membantu proses pengenalan, setiap pertanyaan yang diajukan merupakan penggalan penjelasan yang kami sampaikan terkait negara di mana mereka berhenti. Sehingga metode sosialisasi dengan konsep permainan ini juga menggunakan pola penjelasan berulang dan pertanyaan atas penjelasan tersebut. Misalnya, ketika peserta berhenti pada petak Korea Utara, tim akan menjelaskan informasi dari buku saku terkait negara tersebut. Kemudian pertanyaan akan disampaikan berdasarkan penjelasan yang sudah kami sampaikan. Jawaban pertanyaan juga kami ulangi lagi agar seluruh tim menghafal pengetahuan baru tersebut.

Hal ini terbukti efektif karena menurut pantauan peneliti dua ruangan tersebut mampu meningkatkan minat belajar para peserta. Gambar 3 menunjukkan dua ruangan yang digunakan. Tampak pada ruangan sesi literasi, bagian belakang dari papan permainan, para siswa sangat antusias mengisi tulisan di papan tulis. Kegiatan penyampaian materi literasi diikuti dengan sangat baik oleh para pelajar ditandai dengan banyaknya pertanyaan-pertanyaan yang diajukan. Bahkan para peserta tidak sungkan untuk maju ke depan kelas untuk menyampaikan cita-citanya ketika besar nanti. Para peserta juga tidak sungkan untuk berkisah pengalamannya belajar di kawasan perbatasan.

Namun, dalam konteks pemahaman pendidikan global terkait wawasan dunia, peserta didik masih sangat minim (kurang) pemahamannya terhadap negara-negara di dunia. Beberapa nama atau objek yang berkaitan dengan negara tertentu masih awam di telinga mereka. Sehingga meskipun model permainan adalah menanyakan apa yang sudah kami sebutkan sebelumnya, beberapa kelompok peserta masih mengalami kesulitan untuk menjawab. Tetapi kami menemukan fenomena yang menarik ketika ada beberapa kelompok yang justru sangat kenal dengan K-Pop, khususnya grup musik Blackpink. Bahkan tidak sungkan mereka memeragakan nyanyian dan tarian ala Blackpink di salah satu sesi permainan. Melalui permainan tersebut, kami melihat bahwa para peserta didik terpacu semangatnya untuk saling mengungguli kelompok lain dalam hal pengetahuan umum terkait negara-negara tersebut. 
Menurut kami, peserta didik di SDN 08 Bungkang sangat ingin tahu dan punya minat belajar yang tinggi. Akan tetapi, faktor keterbatasan informasi dan jumlah pengajar menjadikan proses belajar mengajar kurang efektif. Hasil wawancara kami selama proses berlangsung baik dengan Kepala Sekolah menunjukkan bahwa memang sekolah secara sumber daya manusia mengalami kekurangan. Belum ditambah fasilitas sekolah yang kurang memadai. Tentunya sangat menghambat proses belajar mengajar.

Padahal seharusnya menurut Fitrianingsih, dkk (2020: 1) pada era revolusi industri 4.0 bentuk inovasi pembelajaran yang tepat dengan menggunakan metode tanpa jarak atau melalui peralatan digital yang memungkinkan guru dan siswa tetap berkomunikasi tanpa hambatan ruang dan waktu. Namun, temuan kami menujukkan bahwa kondisi ideal tersebut tidak dapat diberlakukan di SDN 08 Bungkang. Ketika kami mengadakan kegiatan sosialisasi bahkan ada beberapa guru yang berhalangan hadir karena hujan. Akhirnya peserta kelas tersebut digabung pada kegiatan yang kami lakukan.

Hal tersebut menjadi temuan bagi tim untuk dapat lebih kontributif terhadap perkembangan dunia pendidikan di Kalimantan Barat. Khususnya dalam kaitan dengan isu-isu hubungan internasional. Kami juga merasa perlu untuk memberikan berbagai alat peraga belajar agar dapat mendukung pembelajaran peserta didik di SDN 08 Bungkang Kecamatan Sekayam terkait pemahaman wawasan global. Inovasi pembelajaran perlu mendapatkan intervensi dari berbagai pihak agar kemaslahatan dunia pendidikan benarbenar dirasakan oleh semua peserta didik, baik di daerah perkotaan maupun pedesaan bahkan di batas negara.

\section{SIMPULAN}

Kesiapan sekolah dalam memberikan pendidikan global pada peserta didik masih dinilai belum memadai. Kami menemukan masih belum terkoordinasinya materi pendidikan global dan bahan ajar Ilmu Pengetahuan Sosial (IPS) pada peserta didik di SDN 08 Bungkang, Kecamatan Sekayam, Kabupaten Sanggau. Melalui kegiatan sosialisasi terlihat bahwa terjadi perubahan pemahaman mengenai wawasan global terkait negara-negara dunia. Hal tersebut dapat menimbulkan kesadaran awal akan uniknya masyarakat dunia. Selain itu, dilakukan juga penyampaian materi terkait pentingnya literasi sebagai jendela dunia. Kegiatan direspon dengan sangat baik oleh peserta didik serta mendapatkan apresiasi dari para guru di SDN 08 Bungkang Kecamatan Sekayam, Kabupaten Sanggau. Selama proses sosialisasi, peserta didik begitu antusias dan interaktif dalam menerima pengetahuan yang kami sampaikan.

Peneliti menyarankan kegiatan sosialisasi sejenis dengan tema "Global Citezenship" perlu dilakukan di kabupaten-kabupaten yang ada di Kalimantan Barat. Bahkan menurut hemat tim, kegiatan ini juga perlu melibatkan para pengajar sebagai peserta untuk menanamkan pemahaman yang sama kepada siswa-siswa. Pihak sekolahsekolah yang ada di daerah, khususnya perbatasan, juga dapat dengan aktif menghias sekolah dengan nuansa masyarakat dunia, seperti bendera negara-negara dunia, objek wisata, foto tokoh dunia, dan sebagainya.

\section{DAFTAR PUSTAKA}

Alfian, A. (2019). "Belajar di bekas rumah dinas guru". Antarafoto.com. Dikutip dari https://www.antarafoto.com/peristiwa/v1551273011/belajar-di-bekas-rumahdinas- guru pada tanggal 18 Mei 2019. 
Badan Pusat Statistik Kalimantan Barat. (2018). Kalimantan Barat dalam angka 2018. Pontianak: Badan Pusat Statistik Kalimantan Barat.

Bappenas. (2015). Rencana pembangunan nasional jangka menengah 2015-2019. Jakarta.

Baylis, J. dan Smith, S. (2005). The Globalization of world politics: An introduction to international relations (3rd ed). Oxford: Oxford University Press.

Bernahrd, K. (2017). “Bupati Sanggau Sebut Tingkat Pendidikan Masih Rendah”. Suara Pemred. Dikutip dari https://www.suarapemredkalbar.com/berita/sanggau/2017/12/13/bupati-sebuttingkat-pendidikan-masih-rendah pada tanggal 18 Mei 2019.

Buzan, B. (2004). From international to world society? English school theory and the social structure of globalisation. Cambridge: Cambridge University Press.

Diaz, C. \& Massialas, X. (1999). Global perspective for educator. Boston : Allyn and Bacon

Fitrianingsih, A, Hasanudin, C., Mujahidin, A., Noeruddin, A dan Novitasari, D. (2020). Mengelola kelas online dengan aplikasi schoology. Jurnal PkM Pengabdian kepada Masyarakat, 3(1), 1-11. Retrieved from https://journal.lppmunindra.ac.id/index.php/pkm/article/view/5212

Hooft, S. V. dan Wim V. (2010). Questioning cosmopolitanism. London: Springer Dordrecht Heidelberg.

Israel, R. (2018). "What does it mean to be a global citizen?". Kosmos Journal. Dikutip dari https://www.kosmosjournal.org/article/what-does-it-mean-to-be-a-globalcitizen/ pada tanggal 18 Mei 2019.

Kompas.com. (2014). “"Nawa Cita", 9 Agenda Prioritas Jokowi-JK”. Kompas.com. Dikutip

dari https://nasional.kompas.com/read/2014/05/21/0754454/.Nawa.Cita.9.Agen da.Prioritas.Jokowi-JK pada tanggal 18 Mei 2019.

Oxfam. What is Global Citizenship?. Dikutip dari https://www.oxfam.org.uk/education/who-we-are/what-is-global-citizenship pada tanggal 18 Mei 2019.

Peraturan Menteri Perencanaan Pembangunan Nasional/Kepala Badan Perencanaan Pembangunan Nasional Republik Indonesia No. 7 Tahun 2018.

Smith, S. dan Owens, P. (2005). "Alternative Approaches to International Theory". Dalam John Baylis dan Steve Smith (penyunting), The Globalization of World Politics: An Introduction to international relations (3rd ed). Oxford: Oxford University Press. 
Sudagung, A. D. (2015). "Peran UNDP Goodwill Ambassador dan Match Against Poverty dalam Pengentasan Kemiskinan Global." Nestor Jurnal Hukum PMIH Universitas Tanjungpura Pontianak. Pontianak: Program Magister Ilmu Hukum UNTAN, 179-193.

Sudagung, A. D. (2018). Beckham dan pesan anti perundungan. Dikutip dari https://www.pontianakpost.co.id/beckham-dan-pesan-anti-perundungan pada tanggal 18 Mei 2019.

Sumaatmadja, N. (1998). Manusia dalam Konteks Sosial, Budaya, dan Lingkungan Hidup. Bandung: Alfabeta

Tye, B. B. \& Tye, K. (1992). Global education: A Study of social change. New York: SUNY Press

Yohanna, S. (2015). Transformasi millenium development goals(mdg's) menjadi post 2015 guna menjawab tantangan pembangunan global baru. 